Biens Symboliques / Symbolic Goods

Revue de sciences sociales sur les arts, la culture et les idées

$7 \mid 2020$

Lire en numérique

\title{
Developments in the Scholarly Use of Digital
} Archive Material

Les évolutions de l'usage savant du patrimoine documentaire en ligne

Los desarrollos del uso erudito del patrimonio documental en línea

\section{Philippe Chevallier}

Translator. Delaina Haslam

\section{OpenEdition}

\section{Journals}

Electronic version

URL: http://journals.openedition.org/bssg/490

DOI: $10.4000 /$ bssg.490

ISSN: 2490-9424

Publisher

Presses universitaires de Vincennes

Electronic reference

Philippe Chevallier, "Developments in the Scholarly Use of Digital Archive Material", Biens Symboliques / Symbolic Goods [Online], 7 | 2020, Online since 20 November 2020, connection on 04 March 2021. URL: http://journals.openedition.org/bssg/490 ; DOI: https://doi.org/10.4000/bssg.490 
BIENS

SYMBOLIQUES

SYMBOLIC

GOODS
SYMBOLIQUES

Revue de sciences sociales sur les arts, la culture er les ides
A Social Science Journal on Arts. Culture and Ideas SYMBOLIC $\infty 2$ GOODS

is leurs racine tra

It des cassolettes d'encens et'finim

fums à la fois. Tout rit, chonte et

loucement ivre. Le printemps est

e; le soleil aide à faire patienter

des êtres qui n'en demandenit pas

gui, ayant l'azur du ciel, disenf

absorbés dans le prodige, jpuisant

la nature l'indifference du bien 2

ateurs du cosmos radieusement dist mi ne comne $n^{\circ} 7 / 2020$ as amion shasm

\section{Lire en numérique} Digital Readings 
Les évolutions de l'usage savant du patrimoine documentaire en ligne
Developments in the Scholarly Use of Digital Archive Material

Philippe Chevalier

traduction | translation

Delaina Haslam



Fig. 1. Page d'accueil de Gallica / Gallica homepage 
L'audience, mais aussi la masse et la diversité de l'offre de Gallica' ${ }^{1}$ la bibliothèque numérique de la Bibliothèque nationale de France et de ses partenaires, en font un lieu d'observation privilégié des types d'appropriation que suscite l'accès au patrimoine documentaire en ligne. La confrontation de deux grandes enquêtes par questionnaire auto-administré (2011 et 2016) permet de dégager des évolutions dans les profils et pratiques déclarés des usager·ère.s attaché·e.s à Gallica et, à travers cet exemple singulier, dans le rapport plus large à l'offre documentaire en ligne en contexte de recherche savante (dédiée à l'acquisition de connaissances). Malgré la richesse des informations collectées, ces enquêtes ont aussitôt une limite pour le/la chercheur.se en sciences sociales : elles obéissent à un souhait premier de connaître les publics et les usages d'objets numériques considérés comme tout constitués, sans interroger les dispositifs techniques, ce qu'ils impliquent et les pratiques plus larges dans lesquelles ils s'inscrivent. Une telle approche s'explique par le besoin premier d'une institution publique comme la Bibliothèque nationale de France d'évaluer régulièrement la qualité de son offre, mais aussi la quantité et la diversité de ses bénéficiaires. Nous espérons que ce cadre étroit puisse cependant, au-delà de Gallica et du rapport au patrimoine en ligne, apporter un éclairage sur les « pratiques savantes ordinaires » (Le Marec \& Mairesse 2017) à l'heure du numérique, même s'il nécessiterait compléments et comparaisons que l'article n'a pas l'ambition de réaliser. Nous nous attarderons sur deux évolutions notables des usages de Gallica en l'espace de cinq ans : la place croissante des recherches personnelles - dans un contexte où les motifs d'usage sont de plus en plus variés et

1. Au 31 mai 2018, Gallica offrait l'accès à 4,3 millions de documents patrimoniaux numérisés de la Bibliothèque nationale de France et de ses partenaires : 2,1 millions de numéros de presse et revues, 1,2 million d'images, 600000 imprimés, 400000 objets, 100000 manuscrits, mais aussi des cartes, des partitions, des enregistrements sonores et des vidéos.
Gallica $^{1}$ users, as well as the volume and range of its content, provide an ideal space for the observation of types of appropriation related to accessing digital archive material. A comparison of two major self-administered questionnaires (in 2011 and 2016) helped identify changes in the profiles of Gallica users and their reported practices, and, via this interesting example, in the wider relationship to online archive content in the context of scholarly research (with the purpose of knowledge acquisition). Despite the wealth of information gathered, these studies also have a limitation for the social science researcher: their initial objective was to know the users and usages of digital objects considered to be fully formed, without questioning their technological functioning, implications, or the wider practices to which they belong. Such an approach can be explained by the primary need of a public institution such as the Bibliothèque nationale de France $(\mathrm{BnF})$ to regularly assess the quality of its collections, and also the number and diversity of its users. However, beyond Gallica and the relationship to online archives, I hope that this narrow framework can shed light on "ordinary scholarly practices" (Le Marec \& Mairesse 2017) in terms of digital research, even if this would require additional information and comparisons which are not in the purview of this article. I focus on two notable developments in usage of Gallica in the space of five years: the growing role of personal research-in a context in which the reasons for use are increasingly varied and interlinkedand the evolution of close reading online. I will remain cautious in my presentation of these observations owing to issues regarding methodology that we will discuss first of all: in view of the explosion of digital practices, building an overall vision of the uses of online

1. Up until 31 May 2018, Gallica offered access to 4.3 million digitized archive documents of the Bibliothèque nationale de France and its partners: 2.1 million newspaper and journal issues; 1.2 million images; 600,000 prints 400,000 objects; and 100,000 manuscripts; as well as maps, sheet music, and audio and videos recordings. 
entremêlés - et l'augmentation de la lecture attentive en ligne. Ces constats resteront prudents pour des questions de méthode que nous exposerons en ouverture : face à l'éclatement des pratiques numériques, construire une vision globale des usages d'une offre en ligne, gratuitement consultable et exportable, est devenu des plus difficile. Pour cette raison, les résultats des questionnaires seront mis en regard d'autres analyses : entretiens, observations vidéo-ethnographiques et analyse des logs de connexion².

\section{La connaissance des usages en ligne de Gallica : précautions méthodologiques}

Malgré l'ambiguïté du terme (Papy 2016), nous désignons ici par «bibliothèque numérique » à la fois, puisqu'ils sont inséparables, un ensemble organisé de documents numériques et un dispositif d'accès à ceux-ci. Faisant suite à celle de 2011, une enquête quantitative auprès des usager·ère.s de Gallica a été menée en octobre 2016 par la société TMO Régions (TMO 2017), dans le cadre d'un projet de recherche porté par la BnF, le labex Obvil et Télécom ParisTech : «Mettre en ligne le patrimoine : évolution des usages, transformation des savoirs ? » De 2011 à 2016, le protocole était sensiblement proche : durant un mois, une invitation à répondre à une enquête était visible sur le site de Gallica avec un lien permettant d'accéder à un questionnaire en ligne. Afin de ne pas déformer les résultats au travers de sollicitations de certains groupes d'usager-ère.s, les fichiers de contacts et les réseaux sociaux n'ont été utilisés qu'après deux semaines d'enquête afin de contrôler leur impact sur ces résultats par comparaison de sous-échantillons (avant et après campagne). Au total, l'enquête

2. Ce principe du croisement des approches guide depuis 2013 les travaux du Bibli-Lab, partenariat de recherche entre la BnF et Télécom ParisTech autour des usages du patrimoine numérique des bibliothèques. Tous les travaux qui suivent ont été conduits dans ce cadre partenarial. content that can be freely viewed and exported has become very difficult. For this reason, the results of questionnaires will be compared with other analysis: interviews; ethnographic video observations; and analysis of access logs ${ }^{2}$.

\section{Knowledge of Online Usage of Gallica: Methodological Precautions}

Despite the ambiguity of the term "digital library" (Papy 2016), I use it in two (inseparable) senses: an organized collection of digital documents and the means to access these documents. Following that of 2011, a quantitative survey of Gallica users was conducted in October 2016 by the "TMO regions" market researcher (TMO 2017), within the framework of a study carried out by the BnF, the Obvil laboratory, and Télécom ParisTech] "Making heritage available online: The development of usage and transformation of knowledge?" The procedure used in 2011 and 2016 was roughly the same: an invitation to respond to a survey was visible for a month on the Gallica website, with a link to an online questionnaire. So as not to distort the results by approaching certain groups of users, contact lists and social networks were only used two weeks in to the survey, so as to control their impact on the original results through the comparison of subset data (before and after the campaign). The 2016 survey collected 7,625 responses in total compared

2. This principle of interconnecting approaches has guided the work of Bibli$\mathrm{Lab}$, a research partnership between the $\mathrm{BnF}$ and Télécom ParisTech (a top French engineering institution) looking into usage of libraries' digital archives, since 2013. All work mentioned henceforth has been carried out within this framework of partnership. 
de 2016 a recueilli sept mille six cent vingt-cinq réponses contre trois mille huit cent vingt-huit en 2011. Cette augmentation est supérieure à celle de l'audience de Gallica entre les deux enquêtes et peut s'expliquer en partie par la plus large visibilité de l'annonce sur le site ${ }^{3}$. Elle vérifie en même temps le très fort attachement des usager·ère-s à la bibliothèque numérique, alors même qu'est a contrario observée une chute des taux de réponse à ce type de

questionnaires en ligne qui ne semble pas prête de s'enrayer.

Cet excellent taux de réponse - évalué à 1,2 \% à partir du nombre de visiteurs uniques estimés sur la période d'enquête ${ }^{4}$ - ne prémunit cependant pas contre les biais, bien au contraire (Loosveldt, Carton, Billiet 2004). Le problème se redouble quand on prétend, comme nous le faisons dans cet article, comparer à cinq ans de distance deux échantillons obtenus à partir d'un protocole qui a lui-même évolué, même à la marge dans notre cas. Contrairement aux enquêtes dans les espaces physiques de la Bibliothèque, il n'est en effet pas possible avec le protocole qui est le nôtre de contrôler l'échantillon en ligne, soit par comparaison avec des données réelles, soit en s'assurant d'un tirage aléatoire au sein de la population visée. Une solution à ce problème est de considérer que ce type d'enquête permet de collecter les réponses des usager-ère·s les plus engagé·e·s, qui ont à la fois un certain degré de connaissance du site et un intérêt personnel à son existence, comme nous y invite l'étude de Ganassali \& Moscarola (2004). Parler de représentativité hors de cette restriction n'aurait pas de sens. Aussi faisons-nous le choix de nommer les répondant·e.s aux deux enquêtes des " gallicanautes » pour les distinguer de

3. La visibilité de l'annonce a été étendue à toutes les pages du site, au-delà de la seule page d'accueil qui ne reçoit que $21 \%$ des visites (chiffre donné pour l'année 2016 par l'outil de mesure d'audience et d'analyse du web Xiti, auquel la $\mathrm{BnF}$ a recours)

4. Chiffre donné par Xiti, cf. note 3. with 3,828 in 2011. This increase is bigger than the increase in Gallica users between the two surveys and can partly be explained by the greater visibility of the advert on the site $^{3}$. At the same time, it proves users' strong attachment to the digital library, even though in contrast there has been a fall in response rates to this type of online questionnaire, which does not appear to be about to slow.

However, the excellent response rate-calculated at $1.2 \%$ of the estimated number of unique visitors during the survey period ${ }^{4}-$ does not in any way preclude bias (Loosveldt, Carton, Billiet 2004). The problem increases when we aim, as I do in this article, to compare data from two samples obtained with five years in between using a procedure that has itself evolved, even if only marginally in the case at hand. Unlike with surveys carried out in the BnF's physical spaces, according to the survey procedure followed, it is not in fact possible to control the online sample, either by comparison with actual data, or by ensuring random selection from the target population. One solution to this problem is to consider that this type of inquiry allows us to gather responses from the most committed users, who have both a certain degree of knowledge of the site and a personal interest in its existence, as Ganassali \& Moscarola's study does (2004). It would not make sense to discuss whether the data are representative or not outside this restriction. Therefore I chose to call respondents to both surveys "Gallicanauts" to distinguish them from other users, including a significant proportion

3. The advert was extended to be visible on all pages of the site, rather than just the home page that only gets $21 \%$ of visits (figure given for 2016 by Xiti, an audience measurement and analysis tool used by the BnF).

4. Figure given by Xiti, cf. note 3 . 
l'ensemble des usager'ère's, dont une part importante ne fait que de très brefs passages sur le site, parfois même en ignorant ce qu'il est exactement ${ }^{5}$.

Au-delà du problème de la représentativité, qui se résout en évitant d'inférer l'usage global à partir de la parole des plus engagé·e.s, se pose la question de l'adéquation des réponses - majoritairement « fermées » dans le cadre d'un questionnaire quantitatif - aux usages réels, dans un environnement numérique en évolution permanente. II est difficile de ne pas projeter, à travers la manière dont les réponses sont à l'avance " codées » par l'enquêteur, des usages présumés, liés en particulier aux représentations que des bibliothécaires peuvent avoir des pratiques savantes légitimes, en particulier celles de lecture. Mettre à jour les représentations que nous avions des "gallicanautes » et écouter la manière dont ils/ elles parlent de leur activité en ligne furent les principaux enjeux de la phase d'entretiens qualitatifs qui a précédé la rédaction du questionnaire de 2016 : quinze entretiens semi-directifs ont ainsi été réalisés avec des gallicanautes de profils variés ayant un usage régulier de la bibliothèque numérique (Beaudouin, Garron, Rollet 2016). Les entretiens, d'une durée comprise entre trente minutes et une heure et quart, se déroulaient de préférence dans l'environnement d'usage de Gallica qui leur était le plus familier (bureau, domicile, etc.). Entre autres adaptations dictées par les entretiens, les finalités possibles de l'usage de Gallica ont été reformulées et enrichies dans le questionnaire en ligne, permettant de dépasser le paradigme de la lecture telle qu'elle était pensée avant les médias informatisés : sur Gallica, on vient « consulter

5. Un projet de recherche sur les logs de connexion aux serveurs de Gallica a ainsi montré que la médiane des temps de session sur Gallica était de douze secondes (Nouvellet, Alché-Buc [d'], Beaudouin, Prieur, Roueff 2017), alors que $69 \%$ des « gallicanautes » ayant répondu à l'enquête déclarent passer habituellement plus de trente minutes sur l'interface et $18 \%$ plus d'une heure. who only spend very short periods of time on the site, sometimes without even knowing exactly what it is ${ }^{5}$.

Beyond the problem of how representative the data are, which is resolved by avoiding inferring general relevance from what the most committed users say, we encounter the issue of how adequate the responses are-the majority of which are "closed" within the framework of a quantitative questionnaire - in light of real users in a digital environment in permanent evolution. It is difficult not to project, owing to the way the responses are "coded" in advance by the researcher, presumed usages, linked in particular to librarians' representations relating to legitimate scholarly practices, in particular those of reading. Updating representations of "Gallicanauts" and hearing the way they talk about their online activity were the main aims of the qualitative interview stage, which preceded the drafting of the 2016 questionnaire: fifteen semi-structured interviews were thus carried out with various profiles of Gallicanaut who used the digital library regularly (Beaudouin, Garron, Rollet 2016). The interviews lasted between thirty minutes and an hour and a quarter, and took place preferably in the environment in which respondents were most used to using Gallica (office, home, etc.). Among other adaptations of the online questionnaire that were dictated by the interviews, the possible reasons for using Gallica were reformulated and developed, allowing us to move beyond the reading paradigm as it stood before online media: users may "view a document closely" on Gallica, but also "explore a domain of interest or theme," "collect documents," or "compose a bibliography," or use it "out

5. A research project on Gallica server access records thus showed that the average length of a session on the site was twelve seconds (Nouvellet d'Alché-Buc, Beaudouin, Prieur, Roueff 2017), while $69 \%$ of the Gallicanauts who responded to the surveys said they usually spent more than thirty minutes on the interface, and $18 \%$ said more than an hour. 
attentivement un document », mais on vient aussi " explorer un domaine ou un thème ", " collecter des documents ", " composer une bibliographie », "par curiosité, pour flâner ». Le questionnaire 2016 s'est également efforcé de faire droits aux motifs épisodiques d'utiliser Gallica, distinguant à côté de ce que l'on vient y faire « à chaque fois ou presque ", ce que l'on fait «souvent » et même « occasionnellement ».

Malgré ces efforts, le recours au déclaratif suppose que l'usager 'ère a une activité en ligne qui présente des régularités (on lui demandera ce qu'il fait « principalement », « habituellement », etc.) et une juste conscience de celle-ci - deux présupposés de moins en moins vérifiés à l'heure de la multi-activité et de ses micro-temporalités. L'usager-ère a de plus en plus de mal à " déconstruire l'ensemble de [ses] activités et [à] avoir une appréhension du temps passé sur [chacune d'elles] » (Beaudouin \& Denis 2014). La confrontation avec des résultats issus d'autres méthodes d'observation et d'analyse des usages de Gallica s'avère donc nécessaire pour étayer nos deux principales hypothèses : des entretiens semi-directifs avec des usager ère-s, qui permettent de comprendre les logiques de choix et les motivations ; des observations vidéo-ethnographiques, qui réinscrivent les parcours de recherche en ligne dans la matérialité de leur environnement ; et enfin une analyse des logs de connexion, qui a l'intérêt de prendre en compte la totalité des connexions, y compris les plus brèves. Ce croisement est une nécessité car il permet de faire varier " l'unité de l'action observée et donc la position de l'observateur » (Denis 2009). II atteint en même temps très vite ses limites car il agrège ce qui n'est jamais exactement comparable, faute de pouvoir observer sur la durée et à travers une multiplicité de canaux (logs, entretiens, vidéos, etc.) le même panel d'usager ère·s - situation idéale mais coûteuse, et dans les faits, rarement réalisée. II faut plutôt considérer que les of curiosity, as casual browsing." The 2016 questionnaire strove to take users' sporadic reasons for using Gallica into account, distinguishing what they logged on to do "every time, or almost every time," from what they "often" logged on to do, and even from what they "occasionally" logged on to do.

Despite these efforts, using a self-assessment approach supposes a "regular" reason for users logging on (since they are asked why they log on "mainly," "often," etc.) and that they are aware of this reason-two presuppositions that are increasingly difficult to verify when it comes to multi-activity and micro-temporalities. It is more and more difficult for users to "separate out their activities and have a clear idea of the time spent on [each one]" (Beaudouin \& Denis 2014). Comparison with results from other methods of observation and analysis of Gallica users is therefore necessary to support my two main assumptions. These take the form of semistructured interviews with users, which help to show the rationale behind choices and motivations; ethnographic video observations, which put online research inquiries into the materiality of their own environment; and finally analysis of access logs, which account for even the briefest visits. This collation is necessary since it allows us to vary the "unity of action observed and therefore the position of the observer" (Denis 2009). At the same time it very quickly reaches its limit since it combines ultimately incomparable data: we cannot observe sample groups of users over time and via multiple channels (logs, interviews, videos, etc.)-which represents an ideal but costly and, in fact, rarely achieved situation. We must rather consider that the two observations formulated come amid a swathe of presumptions which appear worthy of being shared. 
deux constats formulés sont pris dans un faisceau de présomptions qui nous a semblé suffisant pour être partagé.

\section{Porosité des usages et accroissement des «seniors amateurs »}

Premier constat fort d'une enquête à l'autre : l'âge moyen des gallicanautes, traditionnellement plus élevé que celui des salles de lecture de la $\mathrm{BnF}^{6}$, a très nettement augmenté depuis l'enquête de 2011, passant de 48 à 54 ans. Cette captation d'un public plus âgé - le vieillissement des gallicanautes usagers en 2011 et l'augmentation de l'audience ne suffisant pas à expliquer un tel écart - s'éclaire si on la met en relation avec la place prise par la consultation pour effectuer des recherches personnelles. À côté des traditionnelles réponses « études » et « métier », les motifs d'usages proposés par le questionnaire avaient tenu à distinguer le simple «loisir » de la « recherche personnelle ». Cette notion de « recherche personnelle ", inspirée par des enquêtes qualitatives plus anciennes (par exemple : Amar \& Chevallier 2014), devait permettre d'identifier, hors de tout contexte académique ou professionnel, des engagements personnels forts dans une activité de recherche requérant un objectif précis, une temporalité longue et une forme d'autodiscipline (régularité, respect d'une méthode, etc.), à distance du sens qu'a pris désormais le mot « loisir » dans la société industrielle (farniente et non otium). Une projection sur l'ensemble des consultations de Gallica ${ }^{7}$ montre que la recherche personnelle motive désormais $45 \%$ des visites, largement devant le métier (20\%), les loisirs (20\%) et les études (15\%); $64 \%$ des

6. 26 ans en bibliothèque tout public du Haut-de-jardin, 40 ans en bibliothèque de recherche accessible sur accréditation.

7. Afin de mieux quantifier les réponses relatives au motif de la visite, le déclaratif a été converti en nombre de visites, en attribuant une valeur conventionnelle à la fréquence déclarée pour chaque motif et en la combinan avec la fréquence de visite déclarée par les répondant $\cdot e \cdot s$

\section{User "Porosity" and a Growing Number of "Senior Amateurs"}

The first observation made between the two surveys was that the average age of Gallicanauts-traditionally higher than that in the reading rooms of the $\mathrm{BnF}^{6}$-increased sharply after the 2011 survey, rising from 48 to 54 years. The ageing of the Gallicanaut population of 2011 and the increase in audience do not sufficiently explain such a difference. But it is easier to understand this picture of an older audience when we put it into perspective with the role of consulting the archives when carrying out personal research. Among the reasons for use proposed by the questionnaire, alongside the traditional responses of "for studies" and "for work," we now find "for personal research" distinguished from the simple "for leisure." This concept of "personal research," inspired by older qualitative surveys (Amar \& Chevallier 2014, for example), allows the identification, outside an academic or professional context, of strong personal engagements within research with a precise objective, a long time scale, and a form of self-discipline (regularity, adherence to a method, etc.) that is far from the meaning now attached to "leisure" in industrial society (in other words, farniente rather than otium). A projection of Gallica ${ }^{7}$ visits shows that personal research now represents $45 \%$ of visits, which is a long way ahead of "for work" (20\%), "for leisure" (20\%), and "for studies" (15\%); $64 \%$ of Gallicanauts also said they "always, or almost always,"

6. 26 years old in the Haut-de-jardin fully public library; 40 years old in the research library that is accessible by accreditation.

7. In order to better quantify the answers relating to the reason for the visit, the statement was changed to number of visits, attributing a conventional value to the stated frequency for each reason and combining this with respondents' stated frequency of visit. 
gallicanautes par ailleurs déclarent utiliser Gallica pour ce motif de recherche personnelle « à chaque fois ou presque » et $15 \%$ « souvent ». En 2011, même si la question était rédigée légèrement différemment, seul.e.s $52 \%$ des gallicanautes déclaraient se rendre sur Gallica « principalement » pour « des recherches en relation avec un travail personnel » (GMV 2012).

Cette augmentation des formes d'engagement personnel dans le rapport à Gallica peut bien entendu renvoyer tout d'abord à une redistribution, voire un éclatement de l'activité des usager-ère-s en ligne, y compris chez les usager ère.s « historiques " que sont les étudiant·e.s et les chercheurs et chercheuses professionnel-le.s. Comme l'ensemble des gallicanautes, étudiant $\cdot e \cdot s$, chercheurs et chercheuses professionnel.le's sont de moins en moins «monomotifs » (celles et ceux qui le restent ne représentant que $28 \%$ des répondant.e.s) et peuvent ainsi alterner un projet studieux avec du loisir ou de la recherche personnelle. Cette variété des motifs d'usage, qui progresse par rapport à 2011, ne se joue d'ailleurs pas seulement entre les sessions, mais aussi à l'intérieur même des sessions, tramées de fréquentes bifurcations, comme l'a montré une vidéo-ethnographie de dix gallicanautes réalisée par deux chercheuses et un chercheur de Télécom ParisTech dans le cadre du labex Obvil (Rollet, Beaudouin, Garron 2016). L'objectif était de réinscrire les résultats du questionnaire dans l'épaisseur de l'activité humaine, en observant au plus près les parcours d'utilisateurs et utilisatrices habitué.e.s de Gallica. La captation audiovisuelle de l'activité à l'écran était complétée par des entretiens d'auto-confrontation qui permettaient de donner sens aux observations. Celles-ci révèlent en particulier, au sein d'une même séquence de recherche, « d'une part, la capacité des utilisateurs à basculer d'un objectif à un autre et, d'autre part, à manier plusieurs objectifs en même temps, et donc à adopter des postures différentes simultanément »(Rollet et al. 2016). Plutôt used Gallica for the purposes of personal research, and 15\% said they "often" used it for this. In 2011, although the question was worded slightly differently, just $52 \%$ of respondents said that they consulted Gallica "mainly" for "research relating to personal work" (GMV 2012).

This increase in forms of personal engagement with Gallica may of course refer first of all to a redistribution of -or even explosion inusers' online activity, including that of "historic" users-students and professional researchers. As with the entire sample of "Gallicanauts," students and professional researchers are less and less "mono-motivated" (those that remain so represent just $28 \%$ of respondents) and thereby alternate between visits for a study project and visits for leisure or personal research. This variety of reasons for use, which increased from 2011 , is not only played out between sessions, but also within the same session, interwoven with frequent bifurcations, as shown by a video-ethnography of ten Gallicanauts carried out by researchers from Télécom ParisTech within the framework of the Obvil laboratory (Rollet, Beaudouin, Garron 2016). The objective was to re-record the questionnaire results in the thick of human activity, observing the paths of frequent Gallica users up close. The audiovisual recording of screen activity was accompanied by self-confrontation interviews, which helped give the observations meaning. In particular, these reveal "users" capacity within one research sequence to, on the one hand, swing from one objective to another and, on the other, handle several objectives at the same time, thereby adopting different postures simultaneously' (Rollet et al. 2016). Rather than diversity, we should rather talk about "porosity" of uses. 
que de variété, il nous faut donc plutôt parler d'une « porosité » des usages.

Cet entrelacement des motifs, s'il a pu jouer dans l'augmentation des recherches personnelles, en particulier via celles désormais déclarées par les étudiant·e·s et les chercheur·se.s professionnel·le·s, n'est cependant pas le seul facteur explicatif. Le croisement de motifs le plus fréquent est en effet, désormais, celui du loisir et de la recherche personnelle (19\% des répondant·e·s), loin devant tous les autres multi-motifs. Ce chiffre dessine bien les contours d'un public singulier en forte croissance, que l'on peut caractériser, à titre de premier repérage, par a) un usage exclusivement de recherche ou alternant « recherche » et «loisir » hors du cercle professionnel ou académique ; b) un âge plus élevé que la moyenne des «gallicanautes» ; c) une plus forte représentation masculine. Parce qu'il peut être rapproché de la figure traditionnelle de l'amateur, laquelle a accompagné le développement des sciences naturelles (ornithologie, zoologie, botanique) et patrimoniales (histoire), nous qualifierons ce public de « senior amateur ». Rappelons qu'historiquement le terme d'« amateur » ne renvoie pas à une moindre compétence ou une moindre rigueur par rapport au chercheur professionnel, mais à un rapport affectif à l'objet de connaissance, appuyé sur une pratique personnelle experte et un certain degré d'engagement dans cette pratique (Guichard 2008). Sa présence désormais bien visible dans les publics de Gallica peut être mise en regard de la perception accrue du caractère « pour tout le monde » de Gallica - opinion qui passe de 71 à $85 \%$ d'accord en 2016 (croissance encore plus nette sur les «tout à fait d'accord »). Un exemple singulier mais mesurable des usages du patrimoine numérisé va nous permettre d'éclairer cette figure : celui de la Grande Guerre.
While this interlacing of reasons for logging on to Gallica has been a factor in the rise of personal research, in particular regarding personal research by students and professional researchers, it is not the only explanatory factor. The most frequent intersection of reasons is in fact now that of leisure and personal research (19\% of respondents), which is way ahead of all other combinations. This figure provides the outline of a unique group of users that is increasing rapidly, which can be characterized first off as using Gallica a) exclusively for research or alternating between "research" and "leisure" outside the professional and academic spheres; b) being older than the average "Gallicanaut"; c) having a higher representation of men. Since it bears similarities to the traditional figure of amateur that has gone hand in hand with the evolution of natural sciences (ornithology, zoology, botany, etc.) and history, I call this group "Senior Amateurs." It is significant that the term "amateur" does not historically refer to having less skill or taking research less seriously than a professional would, but rather to having an emotional connection to the object of knowledge, supported by an expert personal practice and a certain degree of commitment to it (Guichard 2008). The now very visible presence of amateurs amongst Gallica users can be considered alongside the increased perception of the nature of Gallica as being "for everyone"-an opinion that increased from $71 \%$ to $85 \%$ in agreement in 2016 (with an even greater increase for "completely agree"). Research into the Great War provides a unique but measurable example of digital archive use that will give a clearer picture of this user. 
L'apparition depuis 2011, dans la liste des quinze premiers sites affluents de Gallica ${ }^{8}$, d'un forum de discussions entre chercheurs et chercheuses amateur.trice-s autour de la Grande Guerre, Pages $14-18^{9}$, a révélé l'ampleur du phénomène et semble être en mesure d'illustrer, comme nous allons le voir, les résultats de l'enquête. Créé en 2001, ce forum représente aujourd'hui vingttrois mille membres inscrits et cinq cent mille messages échangés. Ce n'est pas un hasard : cette apparition en 2011 dans le radar des sites affluents est contemporaine de la fin du premier marché de numérisation de masse des imprimés de la $\mathrm{BnF}$ (2007-2011, à raison de cent mille volumes par an) où la période 1914-1918 ne fut pas en reste. Furent ainsi mises à disposition d'un large public, via Gallica, c'est-à-dire gratuitement et à distance, des sources essentielles pour l'étude de cette période. La présence du thème de la Grande Guerre dans les sites affluents, derrière celui plus large de la généalogie - qui peut, dans bien des cas, l'inclure -, a alors convaincu la BnF de lancer une recherche sur le « devenir en ligne du patrimoine numérisé » autour de cette période, afin de mieux comprendre ses appropriations par des communautés d'amateurs sur le web. Ce projet, conduit en 2013-2016 en partenariat avec La Contemporaine (ex-BDIC) et Télécom ParisTech, dans le cadre du labex Les passés dans le présent, a permis de vérifier, à travers des entretiens et une cartographie de cinq cents sites internet français dédiés à la Grande Guerre, non seulement la vitalité sur le web des échanges entre amateurs autour de ce thème, mais aussi la place qu'y occupent les documents numérisés issus de bibliothèques numériques patrimoniales ou portails documentaires (Gallica, Mémoire des hommes, L'Argonnaute, etc.). Après analyse (tous les résultats qui suivent sont extraits de Beaudouin, Chevallier, Maurel

8. Est nommé site affluent un site qui pointe par un hyperlien vers un élément de Gallica et devient ainsi une source de trafic. Les sites affluents, hors sites du domaine bnf fr, représentaient en $201116 \%$ du trafic total de Gallica.

9. Consulté le 29 août 2019
The appearance since 2011 on the list of Gallica's top fifteen referrer URLs ${ }^{8}$ of a discussion forum for amateur researchers on the First World War called Pages 14-18 ${ }^{9}$ reveals the breadth of the phenomenon and appears to illustrate the results of the survey, as we will see. Created in 2001, today this forum has twentythree thousand registered members and five hundred thousand exchanges of messages. This is not a down to chance: its appearance in 2011 on the radar of referrer URLs coincided with the end of the first wave of mass digitization of $\mathrm{BnF}$ printed material (2007-2011, at a rate of one hundred thousand volumes a year), which included the 1914-1918 period. Essential sources for the study of this period were thereby made available, freely and remotely, to a wide audience via Gallica. The presence of the First World War theme among referrer URLs, after the wider theme of genealogy-which may often include the former-thus convinced the BnF to launch research into the "online future of digital archives" around this period, so as to better understand its appropriations by communities of amateurs on the internet. This project, carried out between 2013 and 2016 in partnership with La Contemporaine (exBDIC) and Télécom ParisTech within the framework of Les passés dans le présent laboratory, proved via interviews and a cartography of five hundred French internet sites on the Great War, not only the vitality of exchanges between amateurs on this theme, but also the role of digitized documents from the digital library archives or document portals Gallica, Mémoire des hommes, L’Argonnaute, etc.). After analysis (all the following results are excerpts from Beaudouin, Chevallier, and Maurel 2018, in particular Valérie Beaudouin's chapters entitled "La carte du web consacré à la Grande Guerre", the online map of the Great War, and "Le forum

8. A referrer URL is any site that links to a section of Gallica and thus becomes a source of traffic. Referrer URLs, excluding bnf.fr domain sites, represented $16 \%$ of Gallica's total traffic in 2011.

9. Accessed on 29 August 2019. 
2018, en particulier les chapitres de Valérie Beaudouin : « La carte du web consacré à la Grande Guerre » et "Le forum Pages 14-18 et sa communauté de pratique "), il s'est avéré en effet que plus de la moitié $(54 \%)$ des sites consacrés à la Grande Guerre sur le web français collecté par la BnF au titre du dépôt légal étaient des sites créés et animés par des internautes à titre personnel ou par des associations. L'observation de leurs contenus a montré par ailleurs que les documents patrimoniaux numérisés y étaient fréquemment publiés, commentés, légendés, voire transformés à des fins de connaissance. Sur un forum comme Pages 14-18, dont les données furent analysées de manière automatique, plus d'un message sur deux contient une image ou un lien hypertexte vers un document, et Mémoire des hommes, site du ministère des Armées qui donne accès à 1,3 million de fiches de Morts pour la France, y est le site internet le plus cité, suivi par Gallica. Les citations de liens vers des documents et surtout des images ont d'ailleurs connu une croissance remarquable dans les fils de discussion du forum de 2005 à 2012, cohérente avec l'augmentation sur cette période du nombre de documents accessibles en ligne.
Pages 14-18 et sa communaute de pratique", the Pages 14-18 forum and its community of practice), it became clear that in fact more than half $(54 \%)$ of French websites about the Great War collected by the $\mathrm{BnF}$ under legal deposit were sites created and run by internet users for personal interest or by associations. Observing their content also revealed that digitized archival documents are frequently published, commented on, captioned, and even transformed there for knowledge purposes. On a forum such as Pages 14-18, where data is analysed automatically, more than one in two messages contain an image or hyperlink to a document and Mémoire des hommes, the site of France's Ministry of the Armies that offers access to 1.3 million death records for France, is the most frequently cited website, followed by Gallica. Citations of links to documents and especially images also experienced a remarkable increase in discussion threads on the forum between 2005 and 2012, in line with the increase in the number of documents available online during this period. 


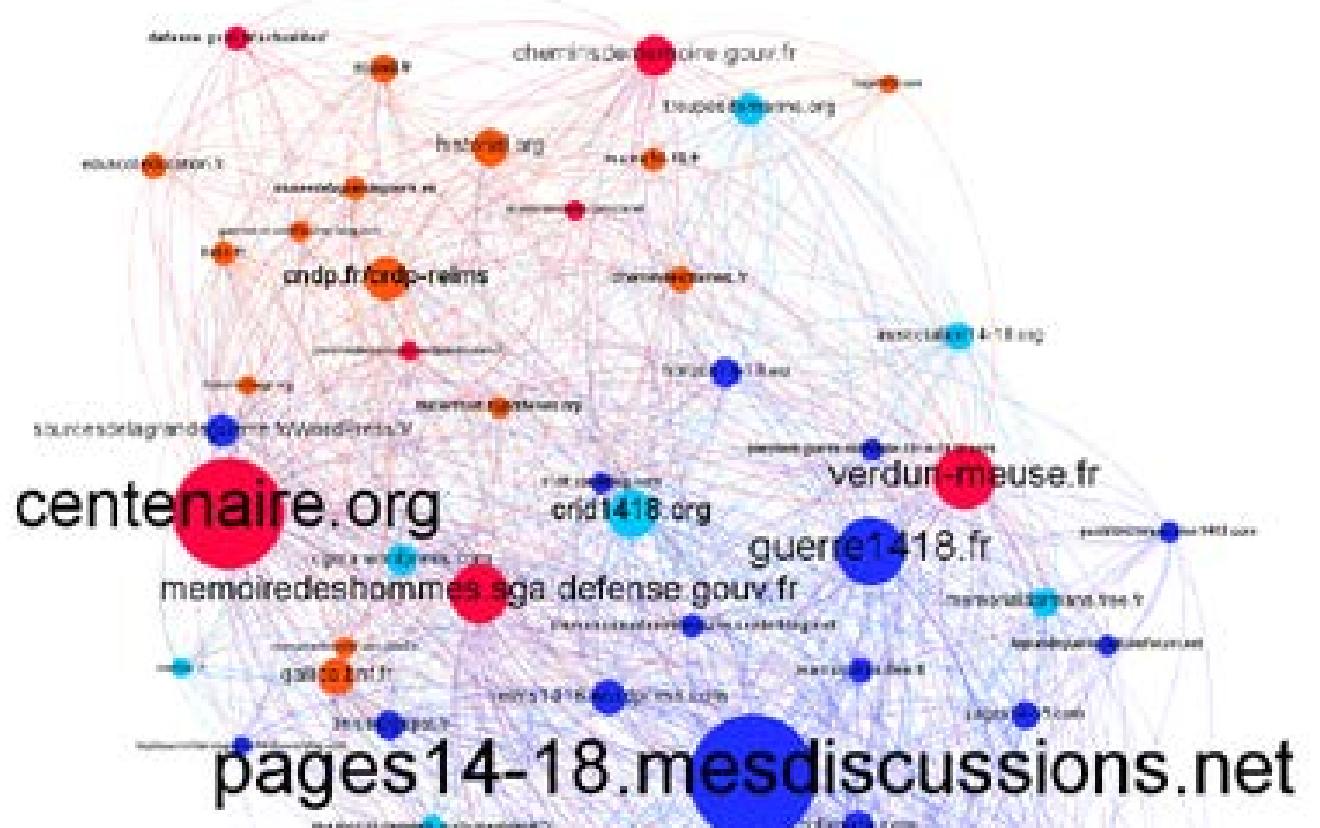

combattant. 1418 easesperso-oranget

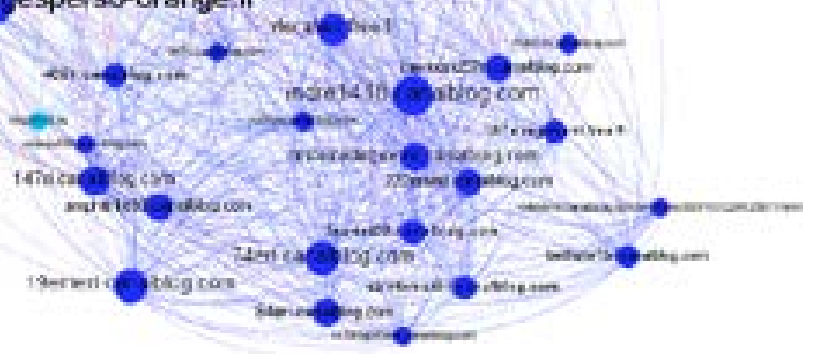

Fig. 2. Carte du web francais de la Grande Guerre / Map of the French web of the Great War

Collecte de novembre 2014, sites avec au moins trente liens entrants et sortants (avec la typologie des sites en légende) / November 2014 data collection with at least thirty incoming and outgoing links (with legend "typology of sites")

Source : Valérie Beaudouin, Zeynep Pehlivan, Télécom ParisTech, Labex Les passés dans le présent 
La mise à disposition gratuite d'une masse critique de documents sur le web par les institutions qui les conservent accompagne, voire suscite, le développement en ligne de communautés d'intérêt où l'échange documentaire raisonné est source de forte valorisation individuelle. Comme le fait remarquer Valérie Beaudouin, ces forums « produisent dans un même mouvement de la connaissance et du lien social » (2016), dans un contexte du web qui facilite la participation des individus indépendamment de leur statut social. La possibilité de partager facilement sa recherche et ses découvertes en ligne démultiplie l'envie de chercher et augmente les ressources personnelles du chercheur amateur via l'échange de bonnes pratiques. À ce titre, le forum de discussions Pages 14-18 témoigne à la fois du haut niveau de spécialisation et de compétence et du fort degré d'engagement personnel que ces études historiques, en lien avec la problématique de la mémoire collective ou individuelle, suscitent sur le web. II joue désormais un rôle de médiateur entre les fonds numérisés par les institutions patrimoniales et leurs publics en ligne.

Si nous regardons maintenant leur identité déclarée, à partir des champs qu'ils/elles sont invitée.es à remplir lors de leur inscription, les usager.ère.s inscrits sur le forum s'écartent de la moyenne de la population française par deux caractéristiques qui les rapprochent en revanche des gallicanautes effectuant des recherches personnelles : la surreprésentation des hommes $(80 \%$ sur le forum) et surtout l'âge plus élevé ( $43 \%$ sur le forum ont 60 ans et plus). L'analyse du forum et le questionnaire auprès des gallicanautes nous mettent donc devant des résultats cohérents qui amènent à s'interroger sur ce qu'il est courant d'appeler la " démocratisation » de l'accès au savoir par le détour d'internet, en particulier en direction des plus jeunes. Si les efforts de diversification des publics ont bien fonctionné en direction des seniors amateurs, on ne peut qu'être frappé en revanche par la
The free provision of a critical mass of documents on the internet by the institutions that hold them supports or even encourages the development of online communities of interest where a careful exchange of documents can be of great value to individuals. As Valérie Beaudouin points out, these forums "produce both knowledge and a social link" (2016) in an online context that allows individuals to participate regardless of their social status. The possibility of sharing their research and discoveries freely online reinforces the amateur researcher's desire to look for and increase their personal resources via the exchange of good practices. The Pages 14-18 discussion forum is thus testament to both the high level of specialization and competence and the high degree of personal commitment that these historical studies encourage on the internet, in relation to the issue of collective or individual memory. Such forums play a mediator role between resources that have been digitized by heritage institutions and their online readership.

If we take a look at their stated identity via the form they are asked to fill in when they sign up to the forum, registered users stand out from the average French population in terms of two characteristics that connect them, rather, to the Gallicanauts who carry out personal research: the overrepresentation of men ( $80 \%$ in the forum), and above all their age ( $43 \%$ in the forum are 60 years old or over). Analysis of the forum and the Gallicanauts questionnaire produce coherent results that invite speculation about what it is commonly referred to as the "democratization" of access to knowledge thanks to the internet, particularly in favour of the young. While diversification efforts have worked well in terms of "senior amateurs," we cannot help but notice the small proportion of students using Gallica (which falls from $21 \%$ to $10 \%$ ), even resulting in a reduction in the estimated number. Consulting "specialist" 
faible part d'étudiant·e.s utilisant Gallica (qui chute de 21 à $10 \%$ ), se traduisant même par un recul en nombre estimé. La consultation des bibliothèques numériques dites spécialisées ou patrimoniales, et sans doute la compréhension même de leur offre, requièrent en effet une familiarité avec la notion de document patrimonial et une connaissance minimale des enjeux de sa numérisation, que certain.e.s enseignant.e.s se plaignent de ne pas trouver chez leurs étudiant.e.s (Amar \& Chevallier 2014). Une étude qualitative européenne vérifie cette difficulté de convaincre les 15-24 ans de l'intérêt d'une bibliothèque numérique spécialisée comme Europeana, jugée à l'aune de Google et Wikipédia (Dobreva, McCulloch, Birrell, Ünal, Feliciati 2010).

Au-delà de la faible représentation des plus jeunes, les principaux écarts entre les connaisseurs de Gallica et la population française portent sur les études longues, les professions et catégories socioprofessionnelles supérieures et la consommation de livres et d'activités culturelles, toutes mieux représentées que dans la moyenne française, comme l'a montré une récente étude de l'Ifop (Ifop 2018). La frontière invisible que trace la connaissance de la $\mathrm{BnF}$ et de ses missions au sein de la société française se retrouve presque à l'identique en ligne : la connaissance de Gallica (un Français sur quatre) ne concerne pas un public beaucoup plus diversifié socialement. Ce n'est donc pas une surprise que $38 \%$ des gallicanautes en 2016 déclarent avoir déjà fréquenté les espaces physiques de la $\mathrm{BnF}$ : ce chiffre, élevé par rapport à la perception que l'on a souvent d'usager 'ère-s trop vite qualifié $\cdot e \cdot s$ de « distante.s ", nous rappelle que les offres physiques et numériques se nourrissent l'une de l'autre. La surreprésentation des parisien.ne.s parmi les gallicanautes (un·e sur quatre réside à Paris et première couronne) vérifie que la proximité avec les établissements de la BnF a un impact sur l'usage en ligne. or "heritage" digital libraries, and no doubt even understanding what they offer, in effect requires a familiarity with the concept of archive material and a minimum knowledge of the issues involved in its digitization that some teachers lament to be lacking in their students (Amar \& Chevallier 2014). A European qualitative study confirms this difficulty of convincing 15-24 year olds of the merits of a specialized digital library such as Europeana, which is measured against Google and Wikipedia (Dobreva, McCulloch, Birrell, Ünal, Feliciati 2010).

In addition to the low representation of young people, the group of those aware of Gallica stands out from the general French population in that its members are more likely to have a postgraduate education, high socio-occupational status, and value reading and cultural activities, as found by a recent Ifop study (Ifop 2018). The invisible boundary surrounding knowledge of the $\mathrm{BnF}$ and its work in French society is almost identical online: knowledge of Gallica (one in four French people) does not reach an audience that is significantly more diverse in social terms. It is therefore unsurprising that $38 \%$ of Gallicanauts in 2016 said they had visited the physical space of the BnF: this figure, which is high in relation to the common perception that leads to users being too-hastily labelled "remote," is a reminder that the physical and the digital aspects of the library fuel one another. The overrepresentation of Parisians among Gallicanauts (one in four lives in Paris and its surrounding suburbs) proves that proximity to the BnF's buildings has an impact on online usage. 


\section{Augmentation de la consultation en ligne : l'interface comme nouveau « partenaire » de recherche}

Deuxième évolution notable par rapport à 2011 : la progression, dans l'usage des documents, de la consultation attentive en ligne: $66 \%$ disent le faire « souvent » ou « à chaque fois ", contre $31 \%$ en 2011. Cette consultation est désormais aussi importante que le téléchargement, pratique dominante en 2011 dans l'usage des documents trouvés sur Gallica et pratique plus largement constitutive du " collectionnisme numérique » observé aujourd'hui chez les chercheurs et chercheuses (Roustan 2016 ; Le Marec \& Mairesse 2017). Derrière l'effet probable de l'amélioration des interfaces de consultation et des modes de connexion à internet (haut débit généralisé), mais aussi des limites du " collectionnisme » qui amène le chercheur ou la chercheuse à affronter à nouveau la matérialité et le temps dans un univers numérique qui semblait au départ d'accès immédiat et sans épaisseur (problèmes de classement, d'espace de stockage et de sauvegarde à partir d'une masse critique de documents numériques possédés), c'est un

autre rapport à l'interface que révèle ce résultat.

En 2011, les publics motivés par des recherches personnelles ou professionnelles préféraient transporter le contenu de Gallica dans leur propre univers - bibliothèque numérique sur son ordinateur, archive papier, etc. - avec un faible usage des fonctionnalités avancées de recherche et de manipulation des documents proposées. Parmi les nouveaux services et fonctionnalités attendus, le téléchargement complet de corpus arrivait en tête $(61 \%)$, soulignant ce rapport " consumériste 》 à Gallica réservoir documentaire avant d'être un dispositif d'accès qui aurait son intérêt propre et serait partie prenante de l'activité de recherche, de lecture et d'interprétation des documents. Ce « déni

\section{An Increase in Online Reading: The Interface as New Research "Partner"}

The second significant development from 2011 is the increase in close reading online when it comes to use of documents: $66 \%$ say that they "often" or "always" do this, compared with 31\% in 2011. This type of viewing is now on the same scale as downloading, which was the main practice in 2011 with regard to documents found on Gallica and a practice that is more generally representative of "digital collectionism" observed among researchers today (Roustan 2016; Le Marec \& Mairesse 2017). With the likely improvement of user interfaces and internet connections (as high-speed broadband spreads) and owing to the limits of "collectionism"-in the sense that the researcher still comes up against materiality and time constraints (problems of classification, storage space, and security for a critical mass of digital documents held) in a digital universe which initially appeared to offer immediate and limitless access - a new relationship to the interface emerges.

In 2011, audiences motivated by personal or professional research preferred to bring the content of Gallica into their own world-the digital library on their computer, a paper archive, etc.-with low usage of the advanced research and document manipulation functions available. Among the new features and services that users said they would like to see, the ability to download the entire corpus came first (61\%), emphasizing a "consumerist" relationship to Gallica which was seen as a document bank before being an access tool in its own right and a part of the activities of research, reading, and interpreting documents. This "denial of the interface" manifested itself first and foremost in the practices 
d'interface » se manifestait en priorité dans les pratiques et les représentations du public motivé par des recherches précises isolé par classification ascendante hiérarchique en deux groupes : les « loisirs spécialisés » $(28 \%)$ et les «pros » $(30 \%)$. À l'opposé, la consultation en ligne était en 2011 le propre des usager ère-s venant par simple curiosité, pour flâner ou se distraire. Comme des entretiens auprès d'usager-ère-s intensifs de Gallica l'avaient préalablement montré (Amar \& Touitou 2013 ; Amar \& Chevallier 2014), le fait de conserver hors ligne le document numérisé, principalement par impression ou téléchargement sous format PDF, était d'abord motivé par l'inquiétude de ne pas être en mesure de le retrouver rapidement à travers une interface complexe, mal maîtrisée, dont le moteur de recherche semblait produire des résultats fluctuants ; mais aussi par le souhait de garder la maitrise de " sa » bibliothèque et d'y adjoindre le cas échéant - dans le cas des bibliothèques numériques personnelles - d'autres sources numériques, y compris celles produites par le chercheur ou la chercheuse lui/elle-même (photographie numérique). Quant à l'impression papier, pratiquée encore « parfois » ou « souvent » par un gallicanaute sur deux en 2011, elle semblait s'imposer en cas de lecture approfondie, suivant l'opinion alors largement partagée que lire en ligne n'est pas vraiment lire (Amar \& Touitou 2013 ;

Amar \& Chevallier 2014)

A contrario, en 2016, le téléchargement complet de corpus chute de 61 à $41 \%$ dans les attentes des gallicanautes; de même que les outils d'annotation des documents (de 52 à $32 \%$ ) et un espace de travail collaboratif (de 28 à $13 \%$ ). Cette dernière baisse est à mettre en regard de l'augmentation du partage de documents de Gallica sur le web : $40 \%$ le font désormais au moins occasionnellement, d'abord sur Facebook, alors qu'ils/elles n'étaient que $13 \%$ en 2011. Les pistes d'améliorations potentielles présentées dans le questionnaire ont également été bien accueillies : elles concernaient and representations of users motivated by specific research, who were categorized into two groups using agglomerative hierarchical clustering: "those with specialist hobbies" $(28 \%)$ and "pros" (30\%). Reading online, on the other hand, was characteristic of users who came out of simple curiosity for casual browsing or amusement. As interviews with intensive users of Gallica had previously shown (Amar \& Touitou 2013; Amar \& Chevallier 2014), the fact of keeping the digital document offline, usually by printing or downloading it in PDF format, was primarily motivated by a fear of not being able to find it quickly owing to a complex interface which they were not good at handling, whose search engine seemed to produce fluctuating results; but also through a desire to keep control of "one's own" library and-in the case of personal digital librarieswhere necessary add other digital sources to it, including those they created themselves (digital photographs). As for paper printing, which was still done "sometimes" or "often" by one in two Gallicanauts in 2011, this seems to happen when thorough reading is required, in accordance with the widely held opinion that reading online is not really reading (Amar \& Touitou 2013; Amar \& Chevallier 2014)

In contrast, downloading the complete corpus fell by $61 \%$ to $41 \%$ in terms of user wishes in 2016; and this was the same for use as a tool for annotating documents ( $52 \%$ to $32 \%$ ), and as a collaborative workspace $(28 \%$ to $13 \%)$. This last decrease should be viewed against the rise in sharing Gallica documents on the internet: $40 \%$ now do this at least occasionally, first and foremost on Facebook, compared with $13 \%$ in 2011 . The potential improvements presented in the questionnaire were also well received: they concerned document conversion tools (cutting, extraction, etc.) (chosen by 
les outils de transformation des documents (découpage, extraction, etc.) (attendus par $49 \%$ ) et les rebonds par hyperlien vers d'autres ressources, de la BnF (47\%) ou de ses partenaires (44\%). Ce bon accueil des améliorations éventuelles prenait place sur fond d'un bon niveau de connaissance et d'usage des fonctionnalités de base : consulter la table des matières ( $58 \%$ l'utilisent « souvent »), modifier le mode d'affichage des documents (43\%), et, surtout, zoomer $(81 \%)$. On objectera à cette bonne appropriation de l'interface que les fonctionnalités avancées (recherche avancée, copie du code du document, récupération via une API, etc.) restent encore largement sous-utilisées, confirmant un phénomène régulièrement observé sur les interfaces de recherche sur le web. Mais cette sous-utilisation ne doit pas être trop vite interprétée comme un déficit de formation des usager ère-s aux techniques de recherche informatisée (Papy 2016) et donc comme une inadaptation des compétences aux interfaces. Comme le montre l'enquête de 2016, « l'expertise » du gallicanaute - mesurée à partir de sa fréquence d'usage des fonctionnalités dans toute leur diversité - n'est aucunement corrélée au plan statistique à son âge, sa catégorie socioprofessionnelle ou son niveau d'étude, mais uniquement à sa fréquence de consultation. L'expertise ne relève donc pas tant de compétences générales que d'un certain cadre d'activité

Cette appréhension plus positive de l'interface et de ses fonctionnalités, que l'enquête de 2016 permet de mesurer, a certainement été portée par l'amélioration de l'ergonomie du site : l'appréciation de la navigation et de l'accessibilité des fonctions de manipulation des documents a ainsi connu une progression de sept points $(27 \%$ et $35 \%$ de réponses «tout à fait d'accord »), tandis que la satisfaction générale connaissait une progression remarquable, le score des « tout à fait satisfait(s) " passant de 36 à $48 \%$. Mais cette vision, centrée sur l'objet technique et
$49 \%$ ); and hyperlinks to other resources, of the $\mathrm{BnF}(47 \%)$ or its partners (44\%). Those who welcomed the potential improvements already possessed a good level of knowledge of Gallica and made good use of its basic features: viewing the table of contents $(58 \%$ do this "often"), changing the document display (43\%), and, above all, zooming in (81\%). It could be argued that although we observe good use of the interface, advanced features (such as advanced search, copying the document code, retrieval via an API, etc.) remain largely under-used, confirming a phenomenon regularly observed on internet search interfaces. But we should not be too quick to attribute this under-use to a deficit in user training in computer search techniques (Papy 2016) and thus to inadequate competence regarding interfaces. As the 2016 survey shows, Gallicanauts' "expertise"-measured by frequency of use of the full range of advanced features - is not in any way correlated to statistics of age, socio-occupational status, or level of education, but exclusively to frequency of visits. Expertise is not, therefore linked so much to general competence but to a certain type of activity.

This more positive perception of the interface recorded in the 2016 survey was certainly aided by the ergonomic development of the site: appreciation of the navigation and accessibility of document manipulation features thus saw an increase of seven points (from $27 \%$ to $35 \%$ "totally agree" responses), while general satisfaction saw a remarkable improvement, with the number of "completely satisfied" responses going from $36 \%$ to $48 \%$. But this vision which focuses on the technical object and its developments, which go through stages to which the user adapts to varying degrees while 
ses développements, qui passeraient par des stades auxquels l'usager-ère s'adapterait plus ou moins bien du dehors, gagne à être enrichie par un autre regard qui part de l'activité humaine et ses interactions, où l'objet technique est vu comme un partenaire et non un point de butée (Denis 2009). La vidéo-ethnographie de gallicanautes régulier·ère·s (Rollet et al. 2017), qui a permis d'observer des recherches en situation naturelle et le plus souvent ouvertes (qui ne se limitent pas à rechercher un document ou une information précise, mais se déploient par exemple autour d'un thème ou d'une période), éclaire cette appréhension positive d'un jour nouveau en attirant notre attention sur deux dimensions de l'usage de Gallica qui ne peuvent apparaître dans le questionnaire, et très rarement dans les entretiens. La première dimension est la place de l'interface dans la structuration d'une recherche et la construction d'un raisonnement, en particulier à travers la manière de consulter et d'évaluer les résultats du moteur de recherche : ces derniers, au gré des surprises ou des déceptions, peuvent amener l'usager-ère à modifier sa stratégie initiale, en se dotant par exemple de buts intermédiaires ou en produisant des « catégorisations fluctuantes », et même, dans certains cas, à " complètement bifurquer dans son argumentation ». « Dans cette idée, les requêtes dans la barre de recherche peuvent se lire comme des étapes de cheminement, d'une réflexion en train de se faire » (Rollet et al. 2017). La seconde dimension est l'écologie de l'utilisation de Gallica, c'est-à-dire son inscription dans un cadre d'activité plus large incluant le corps, d'autres artéfacts numériques ou matériels, mais aussi d'autres personnes (présentes physiquement ou dans la mémoire de l'usager·ère) : il n'y a pas seulement activité sur Gallica, mais également avec Gallica, où l'interface et le dispositif de consultation (ordinateur, téléphone) ne sont pas effacés mais s'insèrent « dans un univers matériel et numérique ouvert (du carnet de notes près du clavier, à Evernote ou Youtube) » au sein remaining on the outside, benefits from being viewed from a different angle-one of human activity and interactions, whereby the technical object is seen as a partner and not as an obstacle (Denis 2009). The video-ethnography of regular Gallicanauts (Rollet et al. 2017) allowed us to observe usually open research (ie, not restricted to a document or precise piece of information, but, for example, on a theme or into a period) in its natural environment, shedding new light on this positive perception by drawing attention to two dimensions of Gallica use which could not feature in the questionnaire and very rarely in interviews. The first dimension is the role of the interface in structuring research and in the construction of a line of inquiry, in particular through the means of viewing and evaluating search engine results: the latter, which are open to surprises and disappointments, can lead to the user changing their initial strategy-by suggesting, for example, interim goals, or producing "fluctuating classifications"-and even, in certain cases, to "completely changing the direction of their argument." "In this idea, search bar queries can be read as steps in an evolving thought process" (Rollet et al. 2017). The second dimension is the ecology of use of Gallica, that is to say its place in a wider context of activity that includes the body, other digital or material artefacts, but also other people (physically present or in the memory of the user): there is not only activity on Gallica, but also with Gallica, whereby the interface and the consultation tool (for e.g., a computer or smart phone) are not erased but fit into "an open, material and digital universe (from the notebook lying by the keyboard to Evernote or YouTube)" within activities which are mutually articulated and structured (Rollet et al. 2017). 
d'activités qui s'articulent et se structurent mutuellement (Rollet

et al. 2017).

Bien entendu, se servir de Gallica comme d'un réservoir de documents - si l'on entend par-là le recours massif au téléchargement, via l'interface, très prégnant dans les enquêtes menées en 2010-2012 ${ }^{10}$ - n'exclut ni les bifurcations dans la recherche, ni l'entrelacement des outils et des activités ; mais le rapport à l'objet technique y est vécu de manière d'abord négative : l'interface est ce dont on cherche à se libérer au plus vite pour effectuer en dehors la véritable activité de lecture, de réflexion ou même de simple organisation du savoir. Ce que l'interface finalement montre d'elle-même à l'usager-ère " collecteur-rice » ou « collectionneur-se », c'est sa capacité de résistance (la lenteur à répondre, le « bruit » du moteur de recherche, etc.). Elle n'existe qu'en tant que frein à la collecte, comme elle n'existe qu'en tant que frein à la consultation quand, par exemple, aux dires d'un usager de la bibliothèque numérique NumDam en 2011 , on se « [tue] les yeux sur un écran à mettre deux heures pour tourner chaque page » (Amar \& Touitou 2013).

Dans les séquences de la vidéo-ethnographie, même si elles se limitent à un certain type d'usages et d'usager ère's (recherches ouvertes, usages réguliers), le site web devient au contraire un partenaire de l'activité de recherche au sein d'un environnement riche en interactions et en présences diverses (parfois sous la « présence obstinée » des messages électroniques). Cette reconnaissance de l'apport propre de l'interface, occasion d'une activité complexe où action et cognition ne cessent de se croiser et

10. II serait intéressant d'étudier comment cet usage « daté » est aujourd'hu profondément renouvelé par les possibilités nouvelles offertes par la fouille de données et les accès de type « API » (application programming interface)
Of course, using Gallica as a document repository-implying a heavy use of downloads via the interface, which was very significant in the surveys carried out in 2010-2012 ${ }^{10}$ - does not rule out either changes of direction in research, nor the interplay of tools and activities; but the relationship to the technical object is experienced primarily negatively: the interface is that which we seek to free ourselves from as quickly as possible to carry out, away from it, the real activity of reading, thought, or even the simple organization of knowledge. What the interface finally reveals of itself to the "collector" or "collectioner" is its capacity for resistance (its slowness to respond, search engine "noise," etc.). It acts only as a brake on collecting, just as it acts as a brake on document viewing when, for example, in the words of a user of the NumDam digital library in 2011, we "kill our eyes looking at a screen for two hours for every page turned" (Amar \& Touitou 2013).

In sequences of the video-ethnography, despite being restricted to a certain type of use and user (open research, regular use), the website becomes, in contrast, a partner in the research activity in an environment rich in interactions and the presence of various others (other people, and sometimes the "stubborn presence" of electronic messages). This recognition of the interface's own contribution, which gives opportunity for complex activity in which action and cognition constantly collide and bounce off one another, facilitates

10. It would be interesting to study how this "outdated" use has been completely overhauled today by the new possibilities offered by data mining and "API" (application programming interface)-type access. 
de se relancer mutuellement, favorise l'installation durable, en ligne, du chercheur ou de la chercheuse. II est par exemple remarquable que l'impression apparente de désordre des résultats du moteur de recherche, motif de grief couramment qualifié de «bruit », peut être dans certains cas recherché par l'usager ère, soucieux.se au contraire de ne pas trop «fermer » à l'avance sa recherche (ainsi de Didier dans la vidéo-ethnographie qui veille à ne surtout pas mettre de guillemets dans sa requête) ; quant au défilement d'une longue liste de résultats, également potentiellement anxiogène, il n'est pas forcément perçue comme une perte de temps, une activité fastidieuse et inutile, mais plutôt comme une activité parfaitement maîtrisée qui permet une évaluation « à gros grain » d'un domaine ou d'un type de documents (Rollet et al. 2017)

La bibliothèque numérique Gallica est l'occasion d'observer, à travers le regard croisé de différentes enquêtes et différentes méthodologies, l'évolution du rapport au patrimoine documentaire numérisé, à la fois du côté des motivations des usager-ère-s (développement des recherches personnelles à fort engagement de type amateur) et de leur activité concrète (l'interface comme partenaire de recherche et non plus comme obstacle à contourner). L'aisance nouvelle devant l'interface, où les défauts bien connus des portails documentaires ou bibliothèques numériques s'inversent en opportunité, où l'usager ère établit ses propres stratégies pour maîtriser la masse et le bruit, et où le document numérique, consulté dans son dispositif technique initial de publication, semble perdre de son hors-champ, pourrait être le signe d'une extension de ce que le discours académique a institué comme le «numérique ». Plus rien ne lui ferait obstacle et, l'aisance appelant la vitesse et la productivité, il se substituerait aux autres supports et médiations du savoir. II n'en est rien, et ce rapport pacifié avec des interfaces qui ne sont plus des objets mystérieux ou perturbateurs - sans même mentionner ici les peurs de superficialité, d'« aplatissement » the sustainable integration of the researcher online. For example it is striking that the apparent impression of disorder in search engine results, which is a subject of complaint commonly referred to as "noise," can be in some cases sought by the user, conscious instead not to "close" his or her research too soon (like Didier in the video-ethnography, who makes sure not to put brackets around his query). Regarding scrolling through a long list of results, which is just as potentially stressful, this is not necessarily perceived as a waste of time-a tedious and unnecessary activity - but rather as an activity to be perfectly mastered that gives a "course-grained" assessment of a domain or a type of document (Rollet et al. 2017).

The Gallica digital library gives a chance to observe, through comparative analysis of different surveys and methodologies, the development of the relationship to digital archive material, both from the perspective of users' reasons for usage (such as a strong commitment to carrying out personal research, as in the figure of the amateur) and that of their concrete activity (the interface as research partner and no longer as an obstacle to overcome). The newfound ease before the interface -whereby well-known flaws of the document portals or digital libraries become opportunities, whereby the user develops their own strategies to control the mass of material and noise, and whereby the digital document, seen in its original technical form as it was on publication, appears to lose its scope-could be a sign of an extension of what academic discourse has established as the "digital." Nothing more could get in its way, and, as ease brought speed and productivity, other media and mediations of knowledge would be replaced. But this is not the case, and this pacified relationship with interfaces, which are no longer mysterious or troubling objects - not to mention the fears of superficiality, of a "flattening out" of knowledge, or of a 
du savoir, de perte du contexte ou de la matérialité, si souvent entendues dans les enquêtes - est peut-être le signe paradoxal qu'elles peuvent trouver leur juste place dans des pratiques intellectuelles qui ne sont jamais simplement " numériques " comme le rappellent Joëlle Le Marec et François Mairesse. C'est même le phénomène opposé que leur ethnographie récente des pratiques savantes ordinaires révèle, même et surtout chez les utilisateurs trices les plus investi.e.s dans les nouveaux outils: "Les dispositifs informatiques semblent (encore) accentuer des tendances divergentes plus qu'elles ne les homogénéisent " (Le Marec \& Mairesse 2017). C'est bien plutôt la grande hétérogénéité des pratiques qu'observe l'anthropologie des savoirs, que ce soit dans la forme de moments distincts de la recherche documentaire, où l'on a tantôt besoin de l'objet et tantôt on se suffit de son image (Roustan 2016), ou celle d'un espace de travail ouvert et peuplé de choses (Rollet et al. 2017).

Philippe Chevallier

Délégation à la stratégie et à la recherche - Bibliothèque nationale de France

\section{Références bibliographiques}

Amar Muriel \& Chevallier Philippe (2014). « Les usages des corpus numérisés de Gallica sur la Grande Guerre », rapport d'étude. BnF. [Consulté le 15 juin 2018.]

Amar Muriel \& TouItou Cécile (2013). « Usages des corpus patrimoniaux numérisés à l'heure de Google Books ». In PAPY Fabrice (dir.). Recherches ouvertes sur le numérique. Paris, Lavoisier : 117-148.

Beaudouin Valérie (2016). "Forums en ligne : des espaces de coproduction de la connaissance et du lien social ». In MARTIN Olivier \& DAGIRAL Éric (dir.). L'Ordinaire d'internet. Paris, Armand Colin : 203-226. loss of context or materiality so often heard in the surveys-is perhaps a paradoxical sign that they can find their rightful place in intellectual practices that are never simply "digital" as Joëlle Le Marec and François Mairesse have suggested. In fact their recent ethnography of ordinary scholarly practices reveals the opposite phenomenon, even - or indeed especially - with regard to the users most invested in the new tools: "Technological devices (still) seem to emphasize divergent trends more than they homogenize them" (Le Marec \& Mairesse 2017). Rather it is the great heterogeneity of practices that is observed by the anthropology of knowledge, whether in the form of different moments in documentary research where we yearn for the object or make do with its image (Roustan 2016), or that of an open work space filled with things (Rollet et al. 2017)

Philippe Chevallie Délégation à la stratégie et à la recherche - Bibliothèque nationale de France

\section{References}

Amar Muriel \& Chevallier Philippe (2014). "Les usages des corpus numérisés de Gallica sur la Grande Guerre." Study report. BnF. [Accessed on 15 June 2018.]

Amar Muriel \& Touitou Cécile (2013). "Usages des corpus patrimoniaux numérisés à l'heure de Google Books." In PAPY Fabrice (ed.). Recherches ouvertes sur le numérique. Paris, Lavoisier: 117-148.

BEAUDOUIN Valérie (2016). "Forums en ligne: des espaces de co-production de la connaissance et du lien social." In MARTIN Olivier \& DAGIRAL Éric (eds.). L'Ordinaire d'internet. Paris, Armand Colin: 203-226. 
Beaudouin Valérie \& Denis Jérôme (2014). " Observer et évaluer les usages de Gallica. Réflexion épistémologique et stratégique ", rapport de recherche. BnF/Telecom ParisTech. [Consulté le 15 juin 2018.]

Beaudouin Valérie, Garron Isabelle, Rollet Nicolas (2016). " Je pars d'un sujet, je rebondis sur un autre : pratiques et usages des publics de Gallica ", étude qualitative exploratoire, rapport final de la phase 1 du projet « Mettre en ligne le patrimoine : transformation des usages, évolutions des savoirs ? ». BnF/labex Obvil/Télécom ParisTech. [Consulté le 15 juin 2018.]

Beaudouin Valérie, Chevaluier Philippe, Maurel Lionel (2018). Le Web français de la Grande Guerre. Réseaux amateurs et institutionnels. Nanterre, Presses universitaires de Paris Nanterre («Les passés dans le présent »).

DENIS Jérôme (2009). "Une autre sociologie des usages ? Pistes et postures pour l'étude des chaînes sociotechniques ", article de synthèse pour le programme TIC \& Migrations. Paris, MSH. [Consulté le 15 juin 2018.]

Dobreva Milena, McCulloch Emma, Birrell Duncan, Ünal Yurdagül, FELICIATI Pierluigi (2010). "Digital Natives and Specialised Digital Libraries : A Study of Europeana Users ». Communications in Computer and Information Science, $96: 4560$

DonNat Olivier (2011). « Pratiques culturelles, 1973-2008. Dynamiques générationnelles et pesanteurs sociales ». Culture études, 7 : 1-36.

Ganassalı Stéphane \& Moscarola Jean (2004). «Protocoles d'enquête et efficacité des sondages par Internet ». Décisions Marketing, 33 : 63-75.

GMV (2012). «Évaluation de l'usage et de la satisfaction de la bibliothèque numérique Gallica et perspectives d'évolution ", rapport détaillé. BnF. [Consulté le 15 juin 2018.]

GuICHARD Charlotte (2008). Les Amateurs d'art à Paris au XVIII siècle. Seyssel, Champ Vallon.
BEAUDOUIN Valérie \& DeNIS Jérôme (2014). "Observer et évaluer les usages de Gallica. Réflexion épistémologique et stratégique." Research report. BnF/Telecom ParisTech. [Accessed on 15 June 2018.]

Beaudouin Valérie, Garron Isabelle, Rollet Nicolas (2016). "Je pars d'un sujet, je rebondis sur un autre: pratiques et usages des publics de Gallica." Exploratory qualitative study, final report for phase 1 of the project "Mettre en ligne le patrimoine: transformation des usages, évolutions des savoirs ?." BnF/labex Obvil/Télécom ParisTech. [Accessed on 15 June 2018.]

Beaudouin Valérie \& Pehlivan Zeynep (2016). "Cartographie de la Grande Guerre sur le Web." Final report for phase 2 of the project "Le devenir en ligne du patrimoine numérisé: l'exemple de la Grande Guerre." [Accessed on 15 June 2018.]

DENIS Jérôme (2009). "Une autre sociologie des usages ? Pistes et postures pour l'étude des chaînes sociotechniques." Overview article for the programme TIC \&Migrations (MSH Paris). [Accessed on 15 June 2018.]

Dobreva Milena, McCulloch Emma, BirRell Duncan, Ünal Yurdagül, FELICIATI Pierluigi (2010). "Digital Natives and Specialised Digital Libraries: A Study of Europeana Users." Communications in Computer and Information Science, 96: 4560.

Donnat Olivier (2011). "Pratiques culturelles, 1973-2008. Dynamiques générationnelles et pesanteurs sociales." Culture études, 7: 1-36.

Ganassali Stéphane \& Moscarola Jean (2004). "Protocoles d'enquête et efficacité des sondages par Internet." Décisions Marketing, 33: 63-75.

GMV (2012). "Évaluation de l'usage et de la satisfaction de la bibliothèque numérique Gallica et perspectives d'évolution." Detailed report. BnF. [Accessed on 15 June 2018.]

Guichard Charlotte (2008). Les Amateurs d'art à Paris au XVIII siècle. Seyssel, Champ Vallon. 
Ifop (à paraître). « Notoriété et image de la BnF auprès de la population française en âge de la fréquenter, Enquête Ifop pour la $\mathrm{BnF}$ », rapport d'étude.

Le MAREC Joëlle \& MaIResse François (2017). Enquête sur les pratiques savantes ordinaires : collectionnisme numérique et environnements matériels. Bordeaux, Le Bord de l'Eau.

Loosveldt Geert, CARTon Ann, Billiet Jaak (2004). « Assessment of Survey Data Quality : A Pragmatic Approach ». International Journal of Market Research, 46(1) : 65-82.

Muñoz-Leiva Francisco, SANChez-Fernandez Juan, Montoro-Rios Francisco, IBANEZ-ZAPATA José (2010). «Improving the Response Rate and Quality in Web-Based Surveys through the Personalization and Frequency of Reminder Mailings ». Quality \& Quantity : International Journal of Methodology, 44(5) : 1037-1052.

Nouvellet Adrien, Beaudouin Valérie, Alché-Buc Florence (D'), Prieur Christophe, RouefF François (2017). "Analyse des traces d'usage de Gallica : Une étude à partir des logs de connexions au site Gallica », rapport de recherche. Télécom ParisTech/BnF. [Consulté le 15 juin 2018.]

PAPY Fabrice (2016). "Bibliothèques numériques et recherche sur le web ». In Roustan Mélanie (dir.). La Recherche dans les institutions patrimoniales. Sources matérielles et ressources numériques. Villeurbanne, Presses de l'Enssib : 58-72.

Rollet Nicolas, Beaudouin Valérie, Garron Isabelle (2017). «Vidéoethnographie des usages de Gallica », rapport final de la phase 2 du projet "Mettre en ligne le patrimoine : transformation des usages, évolutions des savoirs ? ", BnF/labex Obvil/Télécom ParisTech. [Consulté le 15 juin 2018.]

Roustan Mélanie (2016). « La vague numérique et le ressac du réel. Du rapport aux sources des chercheurs en sciences humaines et sociales ». In ROUSTAN Mélanie (dir.). La Recherche dans les institutions patrimoniales. Sources matérielles et ressources numériques. Villeurbanne, Presses de l'Enssib : 170-192.

TMO régions (2017). "Enquête auprès des usagers de la bibliothèque numérique Gallica », rapport d'enquête. BnF. [Consulté le 15 juin 2018.]
Ifop (forthcoming). "Notoriété et image de la BnF auprès de la population française en âge de la fréquenter. Enquête Ifop pour la BnF." Study report.

Le MAREC Joëlle \& MAIRESSE François (2017). Enquête sur les pratiques savantes ordinaires: collectionnisme numérique et environnements matériels. Bordeaux, Le Bord de l'Eau.

Loosveldt Geert, CARton Ann, Billiet Jaak (2004). "Assessment of Survey Data Quality: A Pragmatic Approach." International Journal of Market Research, 46(1): 65-82.

Muñoz-Leiva Francisco, SANChez-Fernandez Juan, Montoro-Rios Francisco, IBANEZ-Zapata José (2010). "Improving the Response Rate and Quality in Web-Based Surveys through the Personalization and Frequency of Reminder Mailings." Quality \& Quantity: International Journal of Methodology, 44(5): 1037-1052.

Nouvellet Adrien, Beaudouin Valérie, Alché-Buc Florence (D'), Prieur Christophe, RouefF François (2017). "Analyse des traces d'usage de Gallica: Une étude à partir des logs de connexions au site Gallica." Research report. Télécom ParisTech/BnF. [Accessed on 15 June 2018.]

PAPY Fabrice (2016). "Bibliothèques numériques et recherche sur le web." In Roustan Mélanie (ed.). La Recherche dans les institutions patrimoniales. Sources matérielles et ressources numériques. Villeurbanne, Presses de l'Enssib: 58-72.

Rollet Nicolas, Beaudouin Valérie, Garron Isabelle (2017). "Vidéoethnographie des usages de Gallica." Final report for phase 2 of the project "Mettre en ligne le patrimoine: transformation des usages, évolution des savoirs?". BnF/labex Obvil/Télécom ParisTech. [Accessed on 15 June 2018.]

Roustan Mélanie (2016). "La vague numérique et le ressac du réel. Du rapport aux sources des chercheurs en sciences humaines et sociales." In Roustan Mélanie (ed.). La Recherche dans les institutions patrimoniales. Sources matérielles et ressources numériques. Villeurbanne, Presses de I'Enssib: 170-192.

TMO régions (2017). "Enquête auprès des usagers de la bibliothèque numérique Gallica." Fieldwork report. BnF. [Accessed on 15 June 2018.] 